Int. J. Dev. Biol. 58: 147-154 (2014)

doi: $10.1387 / \mathrm{ijdb} .130345 \mathrm{wh}$

\title{
Molecular determinants of uterine receptivity
}

\author{
ZHAOWEI TU\#,1,2, HAO RAN" ${ }^{\#, 1,3}$, SHUANG ZHANG ${ }^{1}$, GUOLIANG XIA ${ }^{3}$, BINGYAN WANG ${ }^{*, 1}$ and HAIBIN WANG*,1 \\ ${ }^{1}$ State Key Laboratory of Reproductive Biology, Institute of Zoology, Chinese Academy of Sciences, \\ ${ }^{2}$ Graduate School of the Chinese Academy of Sciences and ${ }^{3}$ State Key Laboratory for Agrobiotechnology, College of \\ Biological Sciences, China Agricultural University, Beijing, PR China
}

\begin{abstract}
Uterine receptivity is defined as a limited period when the uterine environment is conducive to blastocyst acceptance and implantation. Any disturbance of this early pregnancy event will compromise pregnancy success. In this review, we first briefly summarize uterine morphological coordination for the attainment of receptivity, then focus on elucidating the molecular complexity in establishing uterine receptivity and hence embryo implantation. A better understanding of the molecular basis governing uterine receptivity will help to improve the outcome of natural pregnancy and pregnancy conceived via assisted reproductive techniques.
\end{abstract}

KEY WORDS: uterine receptivity, molecular determinants

\section{Introduction}

Uterine receptivity is a condition in which the uterus is suitable for embryo implantation to occur and it lasts just for a limited time. The concept of a window of uterine receptivity or implantation was raised and established by studies employing the embryo transfer technique in the 1960s (Dickmann and Noyes, 1961, Psychoyos, 1966). While day 4 (day 1 = vaginal plug) preimplantation embryos showed severe damage 9 hour after transfer into a day 5 uterus in rats, day 5 blastocysts can implant normally after transfer to either day 4 or day 5 uteri, but not in the uteri beyond day 5 of pregnancy or pseudopregnancy in rats. These findings suggest that the uterus is not constantly receptive to blastocysts and embryo implantation can happen only in a limited period. This notion has been further confirmed in mouse studies employing both normal pregnant and delayed implantation models (Paria et al., 1993b). On the basis of these previous findings, uterine sensitivity to implantation-competent blastocysts is classically divided into three stages: pre-receptive, receptive and refractory phases. During the pre-receptive stage, the uterus is suitable for embryo development but not ready for implantation, while during the receptive stage, the uterus can initiate implantation when there are competent blastocysts. However, during the refractory stage, implantation-competent blastocysts cannot implant into the uterus and the uterus is adverse to blastocyst survival (Wang and Dey, 2006). In mice, the uterus on days 1-3 of pregnancy is conventionally considered to be in the pre-receptive phase. On day 4 of pregnancy the uterus becomes fully receptive following the priming actions of ovarian progesterone and preimplantation estrogen, whereas by late day 5 the uterus is refractory to initiate implantation. In humans, the first 7 days of the secretory phase is considered as the pre-receptive stage, 7-10 days after ovulation as the receptive stage and the rest of the secretory phase is defined as the non-receptive stage (Paria et al., 1993b, Wang and Dey, 2006). In this review, we briefly summarize the uterine morphological coordination for the attainment of receptivity, with a focus on elucidating the involvement of steroid hormones, adhesion factors, growth factors, cytokines, lipid mediators and transcriptional factors in uterine receptivity, hoping to clarify the molecular complexity in establishing uterine receptivity and hence implantation for an improvement in pregnancy outcome.

\section{Uterine morphological coordination for the status of receptivity}

\section{Pinopodes}

Pinopodes are ultrastructural projections on the apical surface of the luminal epithelium, which appear only during the receptive phase. These bulbous cytoplasmic protrusions are the best studied ultrastructural marker of uterine receptivity that are believed to be helpful in the attachment of the blastocyst to the surface of

Abbreviations used in this paper: $\mathrm{ER}$, estrogen receptor; $\mathrm{PR}$, progesterone receptor; FKBP52, FK506 binding protein-4; LIF, leukemia inhibitory factor; COX, cyclooxygenase; Klfs, the Kruppel-like factors, Stat3, signal transducers and activators of transcription 3 .

*Address correspondence to: Bingyan Wang or Haibin Wang. 1 Beichen West Road, Chaoyang District, Beijing 100101, China. Tel: +86-10-64807868.

E-mail: wangby@ioz.ac.cn; hbwang@ioz.ac.cn

\#Note: These authors contributed equally to this work.

Final, author-corrected PDF published online: 8 July 2014.

ISSN: Online 1696-3547, Print 0214-6282 
luminal epithelium. This structure was first discovered in rats and mice by traditional electron microscopic methods and was named as a "pinopod" because of its pinocytotic function (Nilsson, 1958, Nilsson, 1966). In rats, the development of pinopods synchronizes with the window of uterine receptivity. Pinopod number increases on day 4 of pregnancy and becomes more abundant on day 5 when the uterus enters the receptive phase in rats (Psychoyos and Mandon, 1971). During the postimplantation period, pinopod number decreases rapidly (Singh et al., 1996). This developmental change of pinopods in the uterus is highly progesterone dependent, while administration of high doses of estradiol abolishes the pinopod (Martel et al., 1991), highlighting the similarity of hormonal conditioning for pinopod formation with the attainment of uterine receptivity. Therefore, the appearance of pinopods is a well-defined histological marker for uterine receptivity in rats and mice. However, it is still debatable whether human pinopods act the same as that observed in rodents, since human pinopods are structurally and functionally different from rodent pinopods (Quinn et al., 2007).

\section{Luminal closure}

Luminal closure is defined as the closure of uterine lumen during embryo apposition prior to attachment, which is another morpho- logical landmark of uterine receptivity. In rodents, a generalized stromal edema under the influence of ovarian steroid hormones leads to uterine luminal closure (Wang and Dey, 2006). This event supports a closer contact between the luminal epithelium and the blastocysts and is essential for appropriate blastocyst apposition and subsequent attachment. However, the occurrence of luminal closure does not require the presence of blastocysts, since this phenomenon can be observed both in pregnant and pseudopregnant uteri (Wang and Dey, 2006). Progesterone priming has been demonstrated to be essential for luminal closure. Uterine luminal closure fails to occur in mice missing FK506 binding protein-4 (FKBP52), a co-chaperone for full progesterone receptor (PR) function (Tranguch et al., 2005a). Recent evidence shows that cystic fibrosis transmembrane conductance regulator (CFTR) and epithelial $\mathrm{Na}^{+}$channel $(\mathrm{ENaC})$ are the major gatekeepers regulating uterine fluid secretion and reabsorption (Salleh etal., 2005). Activation of $\mathrm{ENaC}$ is required for prostaglandin synthesis and release, which has been proven to be critical for embryo implantation (Ruan et al., 2012). Aberrant upregulation of CFTR or inhibition of uterine ENaC leads to abnormal uterine fluid accumulation and implantation failure. Progesterone has been shown to repress the expression of CFTR while stimulating uterine ENaC induction, which is condu-

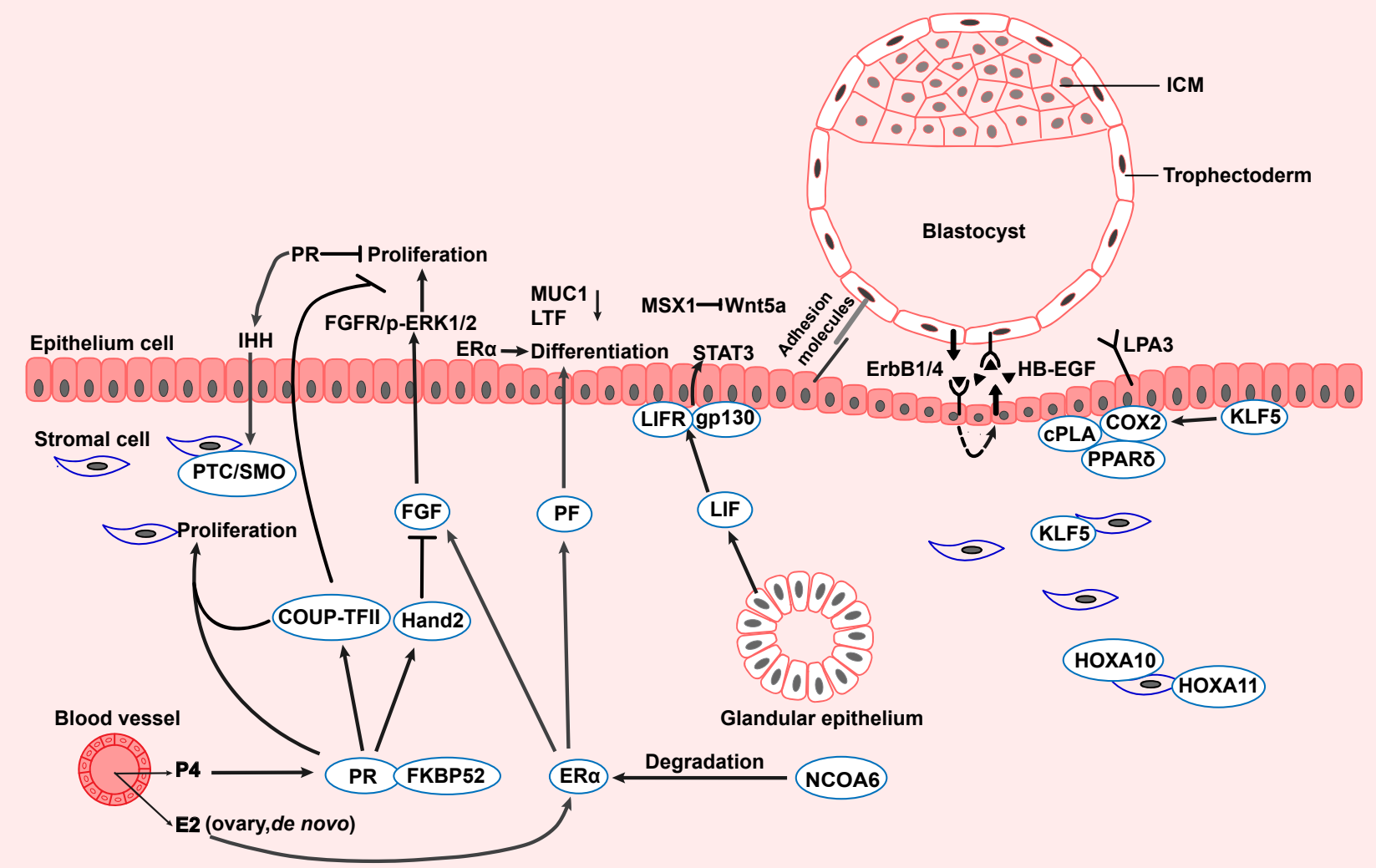

Fig. 1. Hormonal and molecular basis of uterine receptivity. Ovarian steroid hormones in cooperation with a wide range of signaling molecules confer uterine receptivity. CPLA2 $\alpha$, cytosolic phospholipase A2 $\alpha$; COUP-TFIl, chicken ovalbumin upstream promoter transcription factor-2; COX-2, cyclooxygenase-2; E2, 17ß-estradiol; ER, estrogen receptor; PR, progesterone receptor; Hand2, Heart and neural crest derivatives-expressed protein 2; ErbB1/4, epidermal growth factor receptor 1/4; ERK1/2, extracellular signal-regulated kinase 1/2; FGF, fibroblast growth factor; Hoxa10/11, homeobox A10/11; ICM, inner cell mass; LIF, leukemia inhibitory factor; LIFR, LIF receptor; gp 130, glycoprotein 130; LPA3, Iysophosphatidic acid receptor 3; PG, prostaglandin; PPARS, peroxisome proliferator-activating receptor $\delta$; STAT3, signal transducers and activators of transcription 3; HB-EGF, heparin-binding epidermal growth factor-like growth factor; MSX1, Muscle segment homeobox 1; Wnt5a, Wingless-Type MMTV integration site family members 5a; KLF5, Kruppel-like factor 5; FKBP52, FK506-binding protein 52; NCOA6, nuclear receptor coactivator-6; IHH, Indian hedgehog; Ptc, Patched-1. 
cive to embryo implantation (Nobuzane et al., 2008, Zheng et al., 2004). Moreover, it has been shown that serum and glucocorticoid inducible kinase-1 (SGK1), a key regulator of sodium transport in mammalian epithelia (Fejes-Toth et al., 2008), can enhance ENaC expression via inhibiting the ubiquitin ligase, neural precursor cell expressed developmentally down-regulated protein (NEDD) 4-2 (Lang et al., 2006). Its overexpression induces increased $\mathrm{ENaC}$ expression and abolishes normal implantation (Salker et al., 2011). Therefore, it is conceivable that a tightly regulated balance between the uterine fluid secretion and reabsorption is required for timely luminal closure, and hence the attainment of uterine receptivity.

\section{Molecular basis of uterine receptivity}

\section{Estrogen and progesterone signaling}

The conversion of the uterus to competence for embryo implantation is regulated primarily by ovarian steroid hormones, estrogen and progesterone (Dey et al., 2004). Progesterone is necessary for implantation in almost all mammalian species and estrogen is essential for uterine receptivity in the rat and mouse. Maternal estrogen is not required for implantation in some species such as rabbit, hamster, pig and guinea pig; and blastocysts in these species, notably the hamster, pig and rabbit, have the capacity to synthesize estrogen, which may contribute to activation of the implantation process. In other species, including nonhuman primates and the human, estrogen's function in implantation remains inconclusive (Paria et al., 2001b).

Estrogen and progesterone act mainly through nuclear receptors, estrogen receptor (ER) and progesterone receptor (PR), respectively. ER $\alpha$ and ER $\beta$ are two ER isoforms encoded by different genes, while PRA and PRB are generated from the same gene by transcription at different promoters. $\mathrm{ER} \alpha$ is the dominant isoform expressed in mouse uteri (Tan et al., 1999). Previous studies have demonstrated that $\mathrm{ER} \alpha$ is the major mediator in the uterus, while ER $\beta$ plays a minor role in mice (Krege et al., 1998, Lubahn et al., 1993). PRA is the predominant functional isoform in the mouse uterus, since only PRA, but not PRB null mice reproduce PRKO mouse phenotypes in the uterus (Lydon et al., 1995). Both ER and $\mathrm{PR}$ are ligand-dependent nuclear transcription factors and have a complex crosstalk with other signaling pathways.

During the preimplantation period, the uterus undergoes dynamic remodeling (Zhang etal., 2013b). In mice, estrogen promotes uterine water imbibition and increased epithelial cell proliferation during the first two days of pregnancy. After day 3, progesterone derived from newly formed corpora lutea shifts cellular proliferation from the epithelial layer to the stromal bed. On day 4 of pregnancy, stromal cell proliferation is further elevated by increased preimplantation secretion of ovarian estrogen. It has been shown that estrogen promotes epithelial proliferation through the stromal ER $\alpha$ (Cooke et al., 1997). However, both stromal and epithelial ER $\alpha$ are essential for epithelial differentiation and the attainment of uterine receptivity. Ablation of preimplantation estrogen secretion or its action inhibits embryo attachment (Paria et al., 1993b). Under these conditions, embryos will transform into a diapause state, and the uterus enters a neutral phase. This delayed implantation can be maintained for a few weeks by daily progesterone supplementation, whereas a single injection of estrogen can reactivate the embryo and confer uterine receptivity for implantation. Previous studies from the Dey Laboratory have employed this physiologically relevant delayed implantation model to demonstrate that estrogen, within a very narrow dose range, determines the duration of uterine receptivity. For example, at suboptimal doses estrogen fails to confer uterine receptivity, whereas at appropriate estrogen levels the window of uterine receptivity remains open for an extended period, but rapidly closes at higher estrogen levels accompanied by aberrant uterine expression of implantation-related genes (Ma et al., 2003). Therefore, tightly regulated estrogen-ER activity together with progesterone is essential for normal uterine receptivity (as indicated in Fig. 1).

In mice, progesterone can either facilitate or antagonize estrogen action in the context of uterine function. While progesterone inhibits estrogen-induced epithelial proliferation, it cooperates with estrogen to promote stromal cell proliferation. Previous studies employing tissue recombination techniques and uterine conditional PR knockout mouse models have demonstrated that both stromal and epithelial PR are required to antagonize estrogen function in the epithelium (Franco et al., 2012, Kurita et al., 1998, Lydon et al., 1995). In mice lacking the PR co-chaperone, FKBP52, uterine receptivity is disrupted due to exaggerated estrogen activity, which resulted from reduced progesterone activity and failure of uterine epithelial differentiation (Tranguch et al., 2005b). Moreover, a conditional knockout of SRC2, a nuclear receptor coactivator in the uterus, also results in implantation failure (Mukherjee et al., 2006). In addition, null mutations of SRC3 or SRC1 can reduce uterine estrogen responsiveness compromising pregnancy success (Xu et al., 2000, Xu et al., 1998). Uterine-specific deletion of NCOA6 (also known as SRC6), which can accelerate ER $\alpha$ degradation via ubiquitination, also disrupts uterine receptivity and is characterized by increased uterine sensitivity to estrogen and aberrant expression of progesterone-responsive genes (Kawagoe et al., 2012). These findings indicate the complexity and precision of ER and PR signaling that is required for normal uterine receptivity.

Since ER and PR are the primary upstream transcription factors regulating uterine function, increasing evidence has been paid to elucidate the downstream estrogen/progesterone-responsive regulatory molecules and potential coupled signaling cascades. In this respect, $\mathrm{C} / \mathrm{EBP} \beta$, a transcription factor that is responsive to estrogen and progesterone in the uterus has been shown to be essential for normal uterine epithelial and stromal proliferation during implantation (Mantena et al., 2006). Moreover, Hand2 is a progesterone-targeting transcription factor expressed in the uterine stroma and a functional mediator of progesterone in antagonizing estrogen-stimulated epithelial proliferation (Li et al., 2011). Another transcription factor, COUP-TFII, which is mainly expressed in uterine stromal cells, is also required for normal progesterone function. Conditional knockout of COUP-TFII in the mouse uterus leads to implantation failure with disrupted uterine receptivity associated with high estrogen activity (Kurihara et al., 2007). The ER inhibitor ICI182780 treatment can restore normal implantation and decidualization in uterine-COUP-TFIl knockouts (Lee et al., 2010). Besides estrogen/progesterone-targeted transcription factors, Indian hedgehog (Ihh) and its signaling cascade contribute to the regulatory circuit directed by progesterone in the uterus. Ihh and its transmembrane receptor (Ptc1) show a complementary expression pattern in the receptive mouse uterus with the ligand in the epithelium and the receptor in the underlying stroma, respectively (Matsumoto et al., 2002). Uterine conditional depletion of Ihh results in implantation failure (Lee et al., 2006), further suggesting that 
the progesterone-primed Ihh-Ptc1 signaling pathway is critical for normal stromal-epithelial interaction during implantation.

\section{Adhesion molecules}

\section{Integrins}

The integrin family of cell adhesion molecules is a major class of receptors for the ECM and participates in cell-cell and cellsubstratum interactions. They have many functions in cellular processes including differentiation, apoptosis and cell survival, motility and attachment (Desgrosellier and Cheresh, 2010). Previous studies have demonstrated that integrins exhibit distinctive expression patterns in different phases of uterine receptivity in the mouse and human. $\alpha 4 \beta 1$ and $\alpha v \beta 3$ integrins are both present in the mouse uterus at the time of implantation and intrauterine inhibition of these two molecules results in defective implantation (Basak et al., 2002, Illera et al., 2000). $\alpha 1 \beta 1, \alpha 4 \beta 1$, and $\alpha v \beta 3$ integrins are co-expressed in the endometrial epithelium only during the window of implantation in the human (Lessey, 1994). Moreover, decreased expression of $\alpha v \beta 3$ is often associated with unexplained infertility (Lessey et al., 1995).

\section{Selectins}

Selectins, including L-selectin, E-selectin and P-selectin, are another group of cell adhesion molecules, which can bind to carbohydrates. In the human, selectin oligosaccharide-based ligands are upregulated in uterine epithelial cells during the window of receptivity, while L-selectin is expressed in trophoblasts. More interestingly, trophoblasts can bind to selectin ligand-coated beads and to selectin ligand-expressing uterine luminal epithelial cells. These findings demonstrate a functional L-selectin ligand-receptor system in the embryo-uterine dialog during implantation in the human (Genbacev et al., 2003).

\section{Mucins}

Mucins are large molecular weight $O$-linked glycoproteins present on the apical surface of polarized secretory epithelial cells. They can be divided into secreted and transmembrane forms (Surveyor et al., 1995). Muc1 is one of the transmembrane forms. Due to its anti-adhesive nature, Muc1 is an effective barrier preventing embryo attachment to the uterine epithelium. Thus, diminishing Muc1 expression in the uterus facilitates uterine receptivity in many species. In mice, uterine Muc1 expression declines to undetectable levels prior to blastocyst attachment, reinforcing the notion that loss of Muc1 contributes to the establishment of a receptive uterus (Surveyor et al., 1995).

\section{Growth factors}

During the course of revealing the molecular basis governing the blastocyst-uterine dialog during implantation, the Dey Laboratory and collaborators have conducted a robust body of work to address the role of EGF family growth factors in implantation. Several members of the EGF family of growth factors and their receptor subtypes exhibit spatiotemporal expression patterns in the periimplantation uterus. For example, EGFR is detected in the stroma and myometrium while ERBB2 and ERBB3 are predominantly located in epithelial cells (Lim et al., 1997a). In contrast, ERBB4 is detected in a subpopulation of stromal cells (Lim et al., 1998). Moreover, ERBB1 and ERBB4 receptors are highly expressed in the implantation-competent blastocyst trophectoderm (Paria et al., 1993a, Paria et al., 1999). Among the ligands, HB-EGF is specifically expressed in the luminal epithelium surrounding the blastocyst a few hours prior to the attachment reaction (Das et al., 1994). Local release of HB-EGF via Affi-gel beads can induce the expression of implantation-related genes, including its own transcripts, in the receptive uterus (Hamatani et al., 2004, Paria et al., 2001a). More interestingly, implantation-competent blastocysts express high levels of HB-EGF, highlighting the notion that HB-EGF senses the blastocyst-uterine dialog during implantation via an auto-induction loop. Indeed, HB-EGF null mice also show a deferral of on-time implantation, reinforcing the critical role of HB-EGF in implantation (Xie et al., 2007).

\section{Cytokines}

Cytokines are small multifunctional glycoproteins and act as potent intercellular signals regulating uterine function, particularly leukemia inhibitory factor (LIF). In mice, LIF shows a biphasic expression pattern. It is distinctly expressed in the glandular epithelium on day 4 of pregnancy, and with the initiation of embryo implantation, LIF is also expressed in the sub-luminal stroma cells surrounding the implanting embryo (Song et al., 2000). LIF is indispensable for the establishment of uterine receptivity, since LIF null mutant mice exhibit a complete implantation failure with suspended blastocysts within the uterine horn (Chen et al., 2000, Song et al., 2000, Stewart et al., 1992). LIF binds to its receptor LIFR/gp130 and specifically activates Stat3. This signaling pathway, including Stat3 nuclear translocation in the luminal and glandular epithelium, is attenuated in LIF null mutant uteri (Cheng et al., 2001). Recent studies further demonstrate that uterine conditional deletion of Stat3 also induces implantation failure (Lee et al., 2013, Pawar et al., 2013, Sun et al., 2013). In the human, a low level of LIF is associated with unexplained recurrent abortion and infertility (Hambartsoumian, 1998, Piccinni et al., 1998). These findings collectively indicate that the LIF-LIRFR/gp130-Stat3 axis is essential for normal embryo implantation.

\section{Lipid mediators}

The Dey Laboratory has performed pioneering research in elucidating the pathophysiologic significance of endocannabinoid signaling in early pregnancy. Their studies have demonstrated that this lipid signaling pathway is essential for synchronizing embryo development and uterine receptivity for implantation (Wang and Dey, 2006). Anandamide is one of the primary endogenous endocannabinoids. Its levels are lower in the receptive uterus and at implantation sites than in the nonreceptive uterus and at interimplantation sites (Guo et al., 2005, Schmid et al., 1997), suggesting that the lower level of anandamide confers uterine receptivity. Furthermore, expression of the brain-type cannabinoid receptor, $\mathrm{CB} 1$, in the implantation-competent blastocysts is also down-regulated during the uterine receptive stage (Guo et al., 2005, Paria etal., 2001c). In fact, anandamide, within a very narrow concentration range, regulates blastocyst function and implantation by differentially modulating mitogen-activated protein kinase (MAPK) signaling and $\mathrm{Ca}^{2+}$ channel activity via CB1 receptors (Wang et al., 2003). For example, anandamide at a low concentration induces the activation of MAPK signaling, while anandamide at a higher concentration inhibits $\mathrm{Ca}^{2+}$ channel activity and blastocyst competency for implantation without influencing MAPK signaling. 
Aberrant anandamide signaling also leads to miscarriage in women (Habayeb et al., 2008, Maccarrone et al., 2000).

Prostaglandins (PG) have been shown to play a critical role in increasing vascular permeability, a hallmark of embryo implantation. The Dey Laboratory has provided comprehensive physiological and genetic evidence showing that the cPLA2 $\alpha$-COX2-PG signaling axis is essential for successful embryo implantation (Lim et al., 1997b, Song et al., 2002a, Wang et al., 2007, Zhang et al., 2013a). Cytoplasmic phospholipase A2 $\alpha$ (cPLA2 $\alpha$ ) selectively releases arachidonic acid, which can be further converted into $\mathrm{PGH} 2$ by the rate-limiting cyclooxygenase (COX) enzymes, COX-1 and COX-2 (Smith and Dewitt, 1996). In the absence of cPLA2 $\alpha$, the normal window of implantation is altered accompanied by disruptions in embryo spacing, eventually leading to defective post-implantation development of embryos (Song et al., 2002b). These observations introduced the novel concept that the quality of embryo implantation determines term pregnancy success. Moreover, mice with a null mutation for COX-2 show multiple female reproductive deficiencies that span ovulation, fertilization, implantation and decidualization (Lim et al., 1997b). The reproductive defects of COX-2 deficient female mice on a CD1 background are less severe due to COX1 compensation (Wang et al., 2004). Collectively, these findings highlight the physiological significance of the PG signaling axis on implantation. Among various PGs, COX-2 derived prostacyclin is the primary PG produced at the implantation site (Lim et al., 1999a). In mice deficient in the prostacyclin nuclear receptor, peroxisome proliferator activated receptor $\delta$, the window of embryo implantation becomes deferred, reinforcing the necessity of PGs for on-time implantation (Wang et al., 2007). Interestingly, on-time implantation is also linked to the actions of another lipid mediator, lysophospholipids (LP), which signal through the lysophatidic acid receptor, LPA3. LPA3 null mutant females phenotypically mimic the defects observed in cPLA2 $\alpha$ deficient mice showing deferral of the implantation window, embryo crowding, and decreased COX-2 expression (Ye et al., 2005). It is conceivable that LPA3-signaling may function through COX-PG signaling during embryo implantation.

\section{Transcription factors}

\section{Hox family genes}

Homeobox-containing transcription factors are highly conserved regulators during tissue and organ development, as well as in early pregnancy events. In mice, Hoxa10 is expressed in both uterine epithelial and stromal cells with an increased expression during the window of implantation (Satokata et al., 1995). Hoxa10 mutant females show implantation failure (Satokata et al., 1995), with a reduced response to progesterone and estrogen induced stromal cell proliferation (Lim et al., 1999b). Although estrogen stimulated uterine epithelial cell proliferation is unaltered in Hoxa10 deficiency, uterine pinopod number decreases dramatically in the Hoxa10 deficient model (Bagot et al., 2001), suggesting that Hoxa10 is important for epithelial pinopod development and the attainment of uterine receptivity.

Hoxa11, another member of Hox family, is highly expressed in stromal cells of both human and mice, with peak expression at the time of implantation (Gendron et al., 1997, Taylor et al., 1997). Loss of Hoxa11 in mice leads to infertility (Hsieh-Li et al., 1995). Hoxa11 null mutant females exhibit defective glandular differentiation with an absence of LIF expression and stromal cell proliferation in response to ovarian steroids (Gendron et al., 1997). Therefore, Hoxa11 is critical for normal uterine function during implantation.

In contrast to the constitutive contributions of Hoxa10 and Hoxa11, Msx1 (also known as Hox7.1) is distinctly and transiently expressed in the epithelium prior to implantation. With approaching implantation, Msx1 expression decreases on day 4 evening and remains undetectable thereafter. This temporal decrease in Msx1 expression could be essential for conferring uterine receptivity. For example, implantation failure observed in the LIF null mutant uterus is associated with sustained uterine Msx1 expression (Daikokua T, 2004). Conditional deletion of Msx1 in the uterus leads to subfertility due to impaired implantation, whereas deletion of both Msx1 and Msx2 results in infertility due to altered uterine luminal epithelium cell polarity and integrity (Daikoku et al., 2011). This genetic evidence further supports the importance of the timing of Msx1 expression for normal uterine receptivity. Similar to observations in the mouse, Msx1 is also down-regulated in the receptive endometrium in human (Tapia et al., 2011).

\section{The Kruppel-like factors}

The Kruppel-like factors (Klfs) are zinc finger-containing transcription factors implicated in diverse cellular processes, including proliferation, differentiation, apoptosis and development. Among them, Kruppel-like factor 5 (KIf5) is essential for conferring uterine receptivity (Cha et al., 2012). In mouse uteri, Klf5 is spatiotemporally expressed during peri-implantation. On days 1-4 of pregnancy, KIf5 expression is limited to luminal and glandular epithelium. With the initiation of attachment, KIf5 expression shifts to proliferating stromal cells accompanied by a simultaneous decrease in epithelial KIf5 expression. Uterine depletion of Klf5 leads to female infertility due to implantation failure. In Klf5 null mice, the luminal epithelium surrounding the blastocyst remains intact with no signs of apoptotic death, resulting in the retention of the epithelial barrier past the normal window of implantation and impairing blastocyst implantation growth (Sun et al., 2012). These findings demonstrate the importance of Klf5 for embryo implantation.

KIf9, another Kruppel-like transcription factor has been identified as a PR cofactor that can functionally interact with PRA and $\mathrm{PRB}$ in regulating progesterone-responsive gene expression in endometrial epithelial cells (Zhang et al., 2003). Loss of KIf9 in female mice results in reduced fertility due to defective implantation. In KIf9 null females, the expression of Klf13, a highly related family member is upregulated in the uterus, suggesting KIf13 is compensating for the loss of Klf9 during implantation (Simmen et al., 2004). Klf13 null female mice have normal fertility. However, again there is evidence for compensation. Nuclear levels of KIf9 are higher in Klf13 null uteri (Heard et al., 2012). These observations indicate a potential requirement for Klf9 and/or Klf13 in normal uterine function during early pregnancy.

\section{Concluding remarks}

Uterine receptivity involves complex interactions between the different uterine cell types, including the stroma, luminal and glandular epithelium coordinated by a wide range of regulatory molecules and signaling pathways as illustrated in Fig. 1. Ovarian steroid hormones, estrogen and progesterone, act as the commander directing a series of uterine events, such as luminal closure, pinopod formation, as well as coordinated uterine epithelial and stromal cell 
proliferation and differentiation. For example, progesterone via $\mathrm{PR}$ receptors with the aid of the co-chaperone protein, FKBP52, induces the expression of transcription factors, such as Hand2, Hoxa10 and COUP-TFII to confer uterine receptivity (Li et al., 2011, Tranguch et al., 2005b). This transcriptional regulatory circuit is further modulated by various signaling cascades, which are driven by lipids, cytokines, and growth factors, resulting in the construction of a complex, but precisely controlled regulatory network ensuring the success of implantation. These key regulators of implantation have been primarily generated from genetic mouse models. More effort should be directed to the translational aspects of this research, including the development of appropriate molecular markers for endometrial receptivity in human clinical practice.

\section{Acknowledgement}

This review article is dedicated to Dr. S.K. Dey in recognition of his many contributions and promotion of the embryo implantation field. Work incorporated in this article was partially supported by the National Basic Research Program of China (2011CB944400) and the National Natural Science Foundation (81130009 and 81330017). We apologize for unintended omission of any relevant references.

\section{References}

BAGOT, C.N., KLIMAN, H.J. and TAYLOR, H.S. (2001). Maternal Hoxa10 is required for pinopod formation in the development of mouse uterine receptivity to embryo implantation. Dev Dyn 222: 538-544.

BASAK, S., DHAR, R. and DAS, C. (2002). Steroids modulate the expression of alpha4 integrin in mouse blastocysts and uterus during implantation. Biol Reprod 66: 1784-1789.

CHA, J., SUN, X. and DEY, S.K. (2012). Mechanisms of implantation: strategies for successful pregnancy. Nat Med 18: 1754-1767.

CHEN, J.R., CHENG, J.G., SHATZER, T., SEWELL, L., HERNANDEZ, L. and STEWART, C.L. (2000). Leukemia inhibitory factor can substitute for nidatory estrogen and is essential to inducing a receptive uterus for implantation but is not essential for subsequent embryogenesis. Endocrinology 141: 4365-4372.

CHENG, J.G., CHEN, J.R., HERNANDEZ, L., ALVORD, W.G. and STEWART, C.L. (2001). Dual control of LIF expression and LIF receptor function regulate Stat3 activation at the onset of uterine receptivity and embryo implantation. Proc Natl Acad Sci USA 98: 8680-8685.

COOKE, P.S., BUCHANAN, D.L., YOUNG, P., SETIAWAN, T., BRODY, J., KORACH, K.S., TAYLOR, J., LUBAHN, D.B. and CUNHA, G.R. (1997). Stromal estrogen receptors mediate mitogenic effects of estradiol on uterine epithelium. Proc Natl Acad Sci USA 94: 6535-6540.

DAIKOKU, T., CHA, J., SUN, X., TRANGUCH, S., XIE, H., FUJITA, T., HIROTA, Y., LYDON, J., DEMAYO, F., MAXSON, R. et al., (2011). Conditional deletion of MsX homeobox genes in the uterus inhibits blastocyst implantation by altering uterine receptivity. Dev Cell 21: 1014-1025.

DAIKOKUA T, S.H., GUO Y, RIESEQIJK A, MOSSELMAN S, DAS S, AND DEY SK. (2004). Uterine Msx-1 and Wnt signaling becomes aberrant in mice with the loss of leukemia inhibitory factor or Hoxa-10: Evidence for a novel cytokine-homeoboxWnt signaling in implantation. Mol Endocrinol In Press.

DAS, S.K., WANG, X.N., PARIA, B.C., DAMM, D., ABRAHAM, J.A., KLAGSBRUN, M., ANDREWS, G.K. and DEY, S.K. (1994). Heparin-binding EGF-like growth factor gene is induced in the mouse uterus temporally by the blastocyst solely at the site of its apposition: a possible ligand for interaction with blastocyst EGFreceptor in implantation. Development 120: 1071-1083.

DESGROSELLIER, J.S. and CHERESH, D.A. (2010). Integrins in cancer: biological implications and therapeutic opportunities. Nat Rev Cancer 10: 9-22.

DEY, S.K., LIM, H., DAS, S.K., REESE, J., PARIA, B.C., DAIKOKU, T. and WANG, H. (2004). Molecular cues to implantation. Endocr Rev 25: 341-373.

DICKMANN, Z. and NOYES, R.W. (1961). The zona pellucida at the time of implantation. Fertil Steril 12: 310-318.

FEJES-TOTH, G., FRINDT, G., NARAY-FEJES-TOTH, A. and PALMER, L.G. (2008).
Epithelial $\mathrm{Na}+$ channel activation and processing in mice lacking SGK1. Am J Physiol Renal Physiol 294: F1298-F1305.

FRANCO, H.L., RUBEL, C.A., LARGE, M.J., WETENDORF, M., FERNANDEZVALDIVIA, R., JEONG, J.W., SPENCER, T.E., BEHRINGER, R.R., LYDON, J.P. and DEMAYO, F.J. (2012). Epithelial progesterone receptor exhibits pleiotropic roles in uterine development and function. FASEB J 26: 1218-1227.

GENBACEV, O.D., PRAKOBPHOL, A., FOULK, R.A., KRTOLICA, A.R., ILIC, D. SINGER, M.S., YANG, Z.Q., KIESSLING, L.L., ROSEN, S.D. and FISHER, S.J. (2003). Trophoblast L-selectin-mediated adhesion at the maternal-fetal interface. Science 299: 405-408.

GENDRON, R.L., PARADIS, H., HSIEH-LI, H.M., LEE, D.W., POTTER, S.S. and MARKOFF, E. (1997). Abnormal uterine stromal and glandular function associated with maternal reproductive defects in Hoxa-11 null mice. Biol Reprod 56: 1097-1105.

GUO, Y., WANG, H., OKAMOTO, Y., UEDA, N., KINGSLEY, P.J., MARNETT, L.J., SCHMID, H.H., DAS, S.K. and DEY, S.K. (2005). N-acylphosphatidylethanolaminehydrolyzing phospholipase $\mathrm{D}$ is an important determinant of uterine anandamide levels during implantation. J Biol Chem 280: 23429-23432.

HABAYEB, O.M., TAYLOR, A.H., FINNEY, M., EVANS, M.D. and KONJE, J.C. (2008). Plasma anandamide concentration and pregnancy outcome in women with threatened miscarriage. JAMA 299: 1135-1136.

HAMATANI, T., DAIKOKU, T., WANG, H., MATSUMOTO, H., CARTER, M.G., KO, M.S. and DEY, S.K. (2004). Global gene expression analysis identifies molecular pathways distinguishing blastocyst dormancy and activation. Proc Natl Acad Sci USA 101: 10326-10331.

HAMBARTSOUMIAN, E. (1998). Endometrial leukemia inhibitory factor (LIF) as a possible cause of unexplained infertility and multiple failures of implantation. $A m$ J Reprod Immunol 39: 137-143.

HEARD, M.E., PABONA, J.M., CLAYBERGER, C., KRENSKY, A.M., SIMMEN, F.A. and SIMMEN, R.C. (2012). The reproductive phenotype of mice null for transcription factor Kruppel-like factor 13 suggests compensatory function of family member Kruppel-like factor 9 in the peri-implantation uterus. Biol Reprod 87: 115.

HSIEH-LI, H.M., WITTE, D.P., WEINSTEIN, M., BRANFORD, W., LI, H., SMALL, K and POTTER, S.S. (1995). Hoxa 11 structure, extensive antisense transcription, and function in male and female fertility. Development 121: 1373-1385.

ILLERA, M.J., CULLINAN, E., GUI, Y., YUAN, L., BEYLER, S.A. and LESSEY, B.A. (2000). Blockade of the alpha(v)beta(3) integrin adversely affects implantation in the mouse. Biol Reprod 62: 1285-1290.

KAWAGOE, J., LI, Q., MUSSI, P., LIAO, L., LYDON, J.P., DEMAYO, F.J. and XU, J. (2012). Nuclear receptor coactivator-6 attenuates uterine estrogen sensitivity to permit embryo implantation. Dev Cell 23: 858-865.

KREGE, J.H., HODGIN, J.B., COUSE, J.F., ENMARK, E., WARNER, M., MAHLER, J.F., SAR, M., KORACH, K.S., GUSTAFSSON, J.A. and SMITHIES, O. (1998). Generation and reproductive phenotypes of mice lacking estrogen receptor beta. Proc Natl Acad Sci USA 95: 15677-15682.

KURIHARA, I., LEE, D.K., PETIT, F.G., JEONG, J., LEE, K., LYDON, J.P., DEMAYO, F.J., TSAI, M.J. and TSAI, S.Y. (2007). COUP-TFII mediates progesterone regulation of uterine implantation by controlling ER activity. PLoS Genet 3: e102.

KURITA, T., YOUNG, P., BRODY, J.R., LYDON, J.P., O'MALLEY, B.W. and CUNHA G.R. (1998). Stromal progesterone receptors mediate the inhibitory effects of progesterone on estrogen-induced uterine epithelial cell deoxyribonucleic acid synthesis. Endocrinology 139: 4708-4713.

LANG, F., BOHMER, C., PALMADA, M., SEEBOHM, G., STRUTZ-SEEBOHM, N. and VALLON, V. (2006). (Patho)physiological significance of the serum- and glucocorticoid-inducible kinase isoforms. Physiol Rev 86: 1151-1178.

LEE, D.K., KURIHARA, I., JEONG, J.W., LYDON, J.P., DEMAYO, F.J., TSAI, M.J. and TSAI, S.Y. (2010). Suppression of ERalpha activity by COUP-TFII is essential for successful implantation and decidualization. Mol Endocrinol 24: 930-940.

LEE, J.H., KIM, T.H., OH, S.J., YOO, J.Y., AKIRA, S., KU, B.J., LYDON, J.P. and JEONG, J.W. (2013). Signal transducer and activator of transcription-3 (Stat3) plays a critical role in implantation via progesterone receptor in uterus. FASEB J 27: 2553-2563.

LEE, K., JEONG, J., KWAK, I., YU, C.T., LANSKE, B., SOEGIARTO, D.W., TOFTGARD, R., TSAI, M.J., TSAI, S., LYDON, J.P. et al., (2006). Indian hedgehog is a major mediator of progesterone signaling in the mouse uterus. Nat Genet38: 1204-1209.

LESSEY, B.A. (1994). The use of integrins for the assessment of uterine receptivity. Fertil Steril 61 : 812-814 
LESSEY, B.A., CASTELBAUM, A.J., SAWIN, S.W. and SUN, J. (1995). Integrins as markers of uterine receptivity in women with primary unexplained infertility. Fertil Steril 63: 535-542.

LI, Q., KANNAN, A., DEMAYO, F.J., LYDON, J.P., COOKE, P.S., YAMAGISHI, H., SRIVASTAVA, D., BAGCHI, M.K. and BAGCHI, I.C. (2011). The antiproliferative action of progesterone in uterine epithelium is mediated by Hand2. Science 331: 912-916.

LIM, H., DAS, S.K. and DEY, S.K. (1998). erbB genes in the mouse uterus: cellspecific signaling by epidermal growth factor (EGF) family of growth factors during implantation. Dev Biol 204: 97-110.

LIM, H., DEY, S.K. and DAS, S.K. (1997a). Differential expression of the erbB2 gene in the periimplantation mouse uterus: potential mediator of signaling by epidermal growth factor-like growth factors. Endocrinology 138: 1328-1337.

LIM, H., GUPTA, R.A., MA, W.G., PARIA, B.C., MOLLER, D.E., MORROW, J.D., DUBOIS, R.N., TRZASKOS, J.M. and DEY, S.K. (1999a). Cyclo-oxygenase2-derived prostacyclin mediates embryo implantation in the mouse via PPARdelta. Genes Dev 13: 1561-1574.

LIM, H., MA, L., MA, W.G., MAAS, R.L. and DEY, S.K. (1999b). Hoxa-10 regulates uterine stromal cell responsiveness to progesterone during implantation and decidualization in the mouse. Mol Endocrinol 13: 1005-1017.

LIM, H., PARIA, B.C., DAS, S.K., DINCHUK, J.E., LANGENBACH, R., TRZASKOS, J.M. and DEY, S.K. (1997b). Multiple female reproductive failures in cyclooxygenase 2-deficient mice. Cell 91: 197-208.

LUBAHN, D.B., MOYER, J.S., GOLDING, T.S., COUSE, J.F., KORACH, K.S. and SMITHIES, O. (1993). Alteration of reproductive function but not prenatal sexual development after insertional disruption of the mouse estrogen receptor gene. Proc Natl Acad Sci USA 90: 11162-11166.

LYDON, J.P., DEMAYO, F.J., FUNK, C.R., MANI, S.K., HUGHES, A.R., MONTGOMERY, C.A., JR., SHYAMALA, G., CONNEELY, O.M. and O'MALLEY, B.W. (1995). Mice lacking progesterone receptor exhibit pleiotropic reproductive abnormalities. Genes Dev 9: 2266-2278.

MA, W.G., SONG, H., DAS, S.K., PARIA, B.C. and DEY, S.K. (2003). Estrogen is a critical determinant that specifies the duration of the window of uterine receptivity for implantation. Proc Natl Acad Sci USA 100: 2963-2968.

MACCARRONE, M., VALENSISE, H., BARI, M., LAZZARIN, N., ROMANINI, C. and FINAZZI-AGRO, A. (2000). Relation between decreased anandamide hydrolase concentrations in human lymphocytes and miscarriage. Lancet 355: 1326-1329.

MANTENA, S.R., KANNAN, A., CHEON, Y.P., LI, Q., JOHNSON, P.F., BAGCHI, I.C. and BAGCHI, M.K. (2006). C/EBPbeta is a critical mediator of steroid hormoneregulated cell proliferation and differentiation in the uterine epithelium and stroma. Proc Natl Acad Sci USA 103: 1870-1875.

MARTEL, D., MONIER, M.N., ROCHE, D. and PSYCHOYOS, A. (1991). Hormonal dependence of pinopode formation at the uterine luminal surface. Hum Reprod 6: 597-603.

MATSUMOTO, H., ZHAO, X., DAS, S.K., HOGAN, B.L. and DEY, S.K. (2002). Indian hedgehog as a progesterone-responsive factor mediating epithelial-mesenchymal interactions in the mouse uterus. Dev Biol 245: 280-290.

MUKHERJEE, A., SOYAL, S.M., FERNANDEZ-VALDIVIA, R., GEHIN, M., CHAMBON, P., DEMAYO, F.J., LYDON, J.P. and O'MALLEY, B.W. (2006). Steroid receptor coactivator 2 is critical for progesterone-dependent uterine function and mammary morphogenesis in the mouse. Mol Cell Biol 26: 6571-6583.

NILSSON, O. (1958). Ultrastructure of mouse uterine surface epithelium under different estrogenic influences. 2. Early effect of estrogen administered to spayed animals. J Ultrastruct Res 2: 73-95.

NILSSON, O. (1966). Estrogen-induced increase of adhesiveness in uterine epithelium of mouse and rat. Exp Cell Res 43: 239-241.

NOBUZANE, T., TASHIRO, S. and KUDO, Y. (2008). Morphologic effects of epithelial ion channels on the mouse uterus: differences between raloxifene analog (LY117018) and estradiol treatments. Am J Obstet Gynecol 199: 363.e1-6.

PARIA, B.C., DAS, S.K., ANDREWS, G.K. and DEY, S.K. (1993a). Expression of the epidermal growth factor receptor gene is regulated in mouse blastocysts during delayed implantation. Proc Natl Acad Sci USA 90: 55-59.

PARIA, B.C., ELENIUS, K., KLAGSBRUN, M. and DEY, S.K. (1999). Heparin-binding EGF-like growth factor interacts with mouse blastocysts independently of ErbB1:a possible role for heparan sulfate proteoglycans and ErbB4 in blastocyst implantation. Development 126: 1997-2005.
PARIA, B.C., HUET-HUDSON, Y.M. and DEY, S.K. (1993b). Blastocyst's state of activity determines the "window" of implantation in the receptive mouse uterus. Proc Natl Acad Sci USA 90: 10159-10162.

PARIA, B.C., MA, W., TAN, J., RAJA, S., DAS, S.K., DEY, S.K. and HOGAN, B.L. (2001a). Cellular and molecular responses of the uterus to embryo implantation can be elicited by locally applied growth factors. Proc NatIAcad SciUSA 98: 1047-1052.

PARIA, B.C., SONG, H. and DEY, S.K. (2001b). Implantation: molecular basis of embryo-uterine dialogue. Int J Dev Biol 45: 597-605.

PARIA, B.C., SONG, H., WANG, X., SCHMID, P.C., KREBSBACH, R.J., SCHMID, H.H., BONNER, T.I., ZIMMER, A. and DEY, S.K. (2001c). Dysregulated cannabinoid signaling disrupts uterine receptivity for embryo implantation. $J$ Biol Chem 276: 20523-20528.

PAWAR, S., STAROSVETSKY, E., ORVIS, G.D., BEHRINGER, R.R., BAGCHI, I.C and BAGCHI, M.K. (2013). STAT3 Regulates Uterine Epithelial Remodelling and Epithelial-Stromal Crosstalk During Implantation. Mol Endocrinol. 27: 1996-2012.

PICCINNI, M.P., BELONI, L., LIVI, C., MAGGI, E., SCARSELLI, G. and ROMAGNANI, S. (1998). Defective production of both leukemia inhibitory factor and type $2 \mathrm{~T}$-helper cytokines by decidual T cells in unexplained recurrent abortions. Nat Med 4: 1020-1024.

PSYCHOYOS, A. (1966). Recent research on egg implantation. CIBA Foundation Study Group.

PSYCHOYOS, A. and MANDON, P. (1971). [Study of the surface of the uterine epithelium by scanning electron microscope. Observations in the rat at the 4th and 5th day of pregnancy]. C R Acad Sci Hebd Seances Acad Sci D 272: 2723-2725.

QUINN, C., RYAN, E., CLAESSENS, E.A., GREENBLATT, E., HAWRYLYSHYN, P., CRUICKSHANK, B., HANNAM, T., DUNK, C. and CASPER, R.F. (2007). The presence of pinopodes in the human endometrium does not delineate the implantation window. Fertil Steril 87: 1015-1021.

RUAN, Y.C., GUO, J.H., LIU, X., ZHANG, R., TSANG, L.L., DONG, J.D., CHEN, H YU, M.K., JIANG, X., ZHANG, X.H. et al., (2012). Activation of the epithelial Na+ channel triggers prostaglandin $E(2)$ release and production required for embryo implantation. Nat Med 18: 1112-1117.

SALKER, M.S., CHRISTIAN, M., STEEL, J.H., NAUTIYAL, J., LAVERY, S., TREW, G., WEBSTER, Z., AL-SABBAGH, M., PUCHCHAKAYALA, G., FOLLER, M. et al., (2011). Deregulation of the serum- and glucocorticoid-inducible kinase SGK1 in the endometrium causes reproductive failure. Nature Medicine 17: 1509-1513.

SALLEH, N., BAINES, D.L., NAFTALIN, R.J. and MILLIGAN, S.R. (2005). The hormonal control of uterine luminal fluid secretion and absorption. J Membr Biol 206: 17-28.

SATOKATA, I., BENSON, G. and MAAS, R. (1995). Sexually dimorphic sterility phenotypes in Hoxa10-deficient mice. Nature 374: 460-463.

SCHMID, P.C., PARIA, B.C., KREBSBACH, R.J., SCHMID, H.H. and DEY, S.K. (1997). Changes in anandamide levels in mouse uterus are associated with uterine receptivity for embryo implantation. Proc Natl Acad Sci USA 94: 4188-4192.

SIMMEN, R.C., EASON, R.R., MCQUOWN, J.R., LINZ, A.L., KANG, T.J., CHATMAN, L., JR., TILL, S.R., FUJII-KURIYAMA, Y., SIMMEN, F.A. and OH, S.P. (2004) Subfertility, uterine hypoplasia, and partial progesterone resistance in mice lacking the Kruppel-like factor 9/basic transcription element-binding protein-1 (Bteb1) gene. J Biol Chem 279: 29286-29294.

SINGH, M.M., CHAUHAN, S.C., TRIVEDI, R.N., MAITRA, S.C. and KAMBOJ, V.P. (1996). Correlation of pinopod development on uterine luminal epithelial surface with hormonal events and endometrial sensitivity in rat. Eur J Endocrinol 135: 107-17.

SMITH, W.L. and DEWITT, D.L. (1996). Prostaglandin endoperoxide H synthases-1 and -2. Adv Immunol 62: 167-215

SONG, H., LIM, H., DAS, S.K., PARIA, B.C. and DEY, S.K. (2000). Dysregulation of EGF family of growth factors and COX-2 in the uterus during the preattachment and attachment reactions of the blastocyst with the luminal epithelium correlates with implantation failure in LIF-deficient mice. Mol Endocrinol 14: 1147-1161.

SONG, H., LIM, H., PARIA, B.C., MATSUMOTO, H., SWIFT, L.L., MORROW, J. BONVENTRE, J.V. and DEY, S.K. (2002a). Cytosolic phospholipase A2alpha is crucial [correction of A2alpha deficiency is crucial] for 'on-time'embryo implantation that directs subsequent development. Development 129: 2879-2889.

SONG, H., LIM, H., PARIA, B.C., MATSUMOTO, H., SWIFT, L.L., MORROW, J., BONVENTRE, J.V. and DEY, S.K. (2002b). Cytosolic phospholipase A2alpha is crucial for 'on-time' embryo implantation that directs subsequent development. Development 129: 2879-2889. 
STEWART, C.L., KASPAR, P., BRUNET, L.J., BHATT, H., GADI, I., KONTGEN, F. and ABBONDANZO, S.J. (1992). Blastocyst implantation depends on maternal expression of leukaemia inhibitory factor. Nature 359: 76-79.

SUN, X., BARTOS, A., WHITSETT, J.A. and DEY, S.K. (2013). Uterine deletion of gp130 or stat3 shows implantation failure with increased estrogenic responses. Mol Endocrinol 27: 1492-1501.

SUN, X., ZHANG, L., XIE, H., WAN, H., MAGELLA, B., WHITSETT, J.A. and DEY, S.K. (2012). Kruppel-like factor 5 (KLF5) is critical for conferring uterine receptivity to implantation. Proc Natl Acad Sci USA 109: 1145-1150.

SURVEYOR, G.A., GENDLER, S.J., PEMBERTON, L., DAS, S.K., CHAKRABORTY, I., JULIAN, J., PIMENTAL, R.A., WEGNER, C.C., DEY, S.K. and CARSON, D.D. (1995). Expression and steroid hormonal control of Muc-1 in the mouse uterus. Endocrinology 136: 3639-3647.

TAN, J., PARIA, B.C., DEY, S.K. and DAS, S.K. (1999). Differential uterine expression of estrogen and progesterone receptors correlates with uterine preparation for implantation and decidualization in the mouse. Endocrinology 140: 5310-5321.

TAPIA, A., VILOS, C., MARIN, J.C., CROXATTO, H.B. and DEVOTO, L. (2011). Bioinformatic detection of E47, E2F1 and SREBP1 transcription factors as potential regulators of genes associated to acquisition of endometrial receptivity. Reprod Biol Endocrinol 9: 14.

TAYLOR, H.S., VANDEN HEUVEL, G.B. and IGARASHI, P. (1997). A conserved Hox axis in the mouse and human female reproductive system: late establishment and persistent adult expression of the Hoxa cluster genes. Biol Reprod57: 1338-1345.

TRANGUCH, S., CHEUNG-FLYNN, J., DAIKOKU, T., PRAPAPANICH, V., COX, M.B., XIE, H., WANG, H., DAS, S.K., SMITH, D.F. and DEY, S.K. (2005a). Cochaperone immunophilin FKBP52 is critical to uterine receptivity for embryo implantation. Proc Natl Acad Sci USA 102: 14326-14331.

TRANGUCH, S., CHEUNG-FLYNN, J., DAIKOKU, T., PRAPAPANICH, V., COX, M.B., XIE, H., WANG, H., DAS, S.K., SMITH, D.F. and DEY, S.K. (2005b). Cochaperone immunophilin FKBP52 is critical to uterine receptivity for embryo implantation Proc Natl Acad Sci USA 102: 14326-14331.

WANG, H. and DEY, S.K. (2006). Roadmap to embryo implantation: clues from mouse models. Nat Rev Genet 7: 185-199.

WANG, H., MA, W.G., TEJADA, L., ZHANG, H., MORROW, J.D., DAS, S.K. and DEY, S.K. (2004). Rescue of female infertility from the loss of cyclooxygenase-2 by compensatory up-regulation of cyclooxygenase- 1 is a function of genetic makeup. J Biol Chem 279: 10649-10658.
WANG, H., MATSUMOTO, H., GUO, Y., PARIA, B.C., ROBERTS, R.L. and DEY, S.K. (2003). Differential G protein-coupled cannabinoid receptor signaling by anandamide directs blastocyst activation for implantation. Proc Natl Acad Sci USA 100: 14914-14919.

WANG, H., XIE, H., SUN, X., TRANGUCH, S., ZHANG, H., JIA, X., WANG, D., DAS, S.K., DESVERGNE, B., WAHLI, W. et al., (2007). Stage-specific integration of maternal and embryonic peroxisome proliferator-activated receptor delta signaling is critical to pregnancy success. $J$ Biol Chem 282: 37770-37782.

XIE, H., WANG, H., TRANGUCH, S., IWAMOTO, R., MEKADA, E., DEMAYO, F.J., LYDON, J.P., DAS, S.K. and DEY, S.K. (2007). Maternal heparin-binding-EGF deficiency limits pregnancy success in mice. Proc Natl Acad Sci USA 104: 18315-18320

XU, J., LIAO, L., NING, G., YOSHIDA-KOMIYA, H., DENG, C. and O'MALLEY, B.W. (2000). The steroid receptor coactivator SRC-3 (p/CIP/RAC3/AIB1/ACTR/TRAM-1) is required for normal growth, puberty, female reproductive function, and mammary gland development. Proc Natl Acad Sci USA 97: 6379-6384.

XU, J., QIU, Y., DEMAYO, F.J., TSAI, S.Y., TSAI, M.J. and O'MALLEY, B.W. (1998). Partial hormone resistance in mice with disruption of the steroid receptor coactivator-1 (SRC-1) gene. Science 279: 1922-1925.

YE, X., HAMA, K., CONTOS, J.J., ANLIKER, B., INOUE, A., SKINNER, M.K., SUZUKI, H., AMANO, T., KENNEDY, G., ARAI, H. et al., (2005). LPA3-mediated lysophosphatidic acid signalling in embryo implantation and spacing. Nature 435: 104-108.

ZHANG, S., KONG, S., LU, J., WANG, Q., CHEN, Y., WANG, W., WANG, B. and WANG, H. (2013a). Deciphering the molecular basis of uterine receptivity. Mol Reprod Dev 80: 8-21.

ZHANG, S., LIN, H., KONG, S., WANG, S., WANG, H. and ARMANT, D.R. (2013b) Physiological and molecular determinants of embryo implantation. Mol Aspects Med 34: 939-980.

ZHANG, X.L., ZHANG, D., MICHEL, F.J., BLUM, J.L., SIMMEN, F.A. and SIMMEN, R.C. (2003). Selective interactions of Kruppel-like factor 9/basic transcription element-binding protein with progesterone receptor isoforms $A$ and $B$ determine transcriptional activity of progesterone-responsive genes in endometrial epithelial cells. J Biol Chem 278: 21474-21482.

ZHENG, X.Y., CHEN, G.A. and WANG, H.Y. (2004). Expression of cystic fibrosis transmembrane conductance regulator in human endometrium. Hum Reprod 19: 2933-2941. 


\section{Further Related Reading, published previously in the Int. J. Dev. Biol.}

Regulation of germ cell meiosis in the fetal ovary

Cassy M. Spiller, Josephine Bowles and Peter Koopman

Int. J. Dev. Biol. (2012) 56: 779-787

http://dx.doi.org/10.1387/ijdb.120142pk

Local regulation of implantation at the human fetal-maternal interface

Evdokia Dimitriadis, Guiying Nie, Natalie J. Hannan, Premila Paiva and Lois A. Salamonsen Int. J. Dev. Biol. (2010) 54: 313-322

http://dx.doi.org/10.1387/ijdb.082772ed

Implantation: molecular basis of embryo-uterine dialogue

B C Paria, H Song and S K Dey

Int. J. Dev. Biol. (2001) 45: 597-605

http://dx.doi.org/10.1387/ijdb.11417904

Epithelial cell polarity and embryo implantation in mammals

$M$ Thie, P Fuchs and H W Denker

Int. J. Dev. Biol. (1996) 40: 389-393

http://dx.doi.org/10.1387/ijdb.8735953

Expression pattern of different gap junction connexins is related to embryo implantation R Grümmer, B Reuss and E Winterhager

Int. J. Dev. Biol. (1996) 40: 361-367

http://dx.doi.org/10.1387/ijdb.8735949

5 yr ISI Impact Factor $(2011)=2.959$
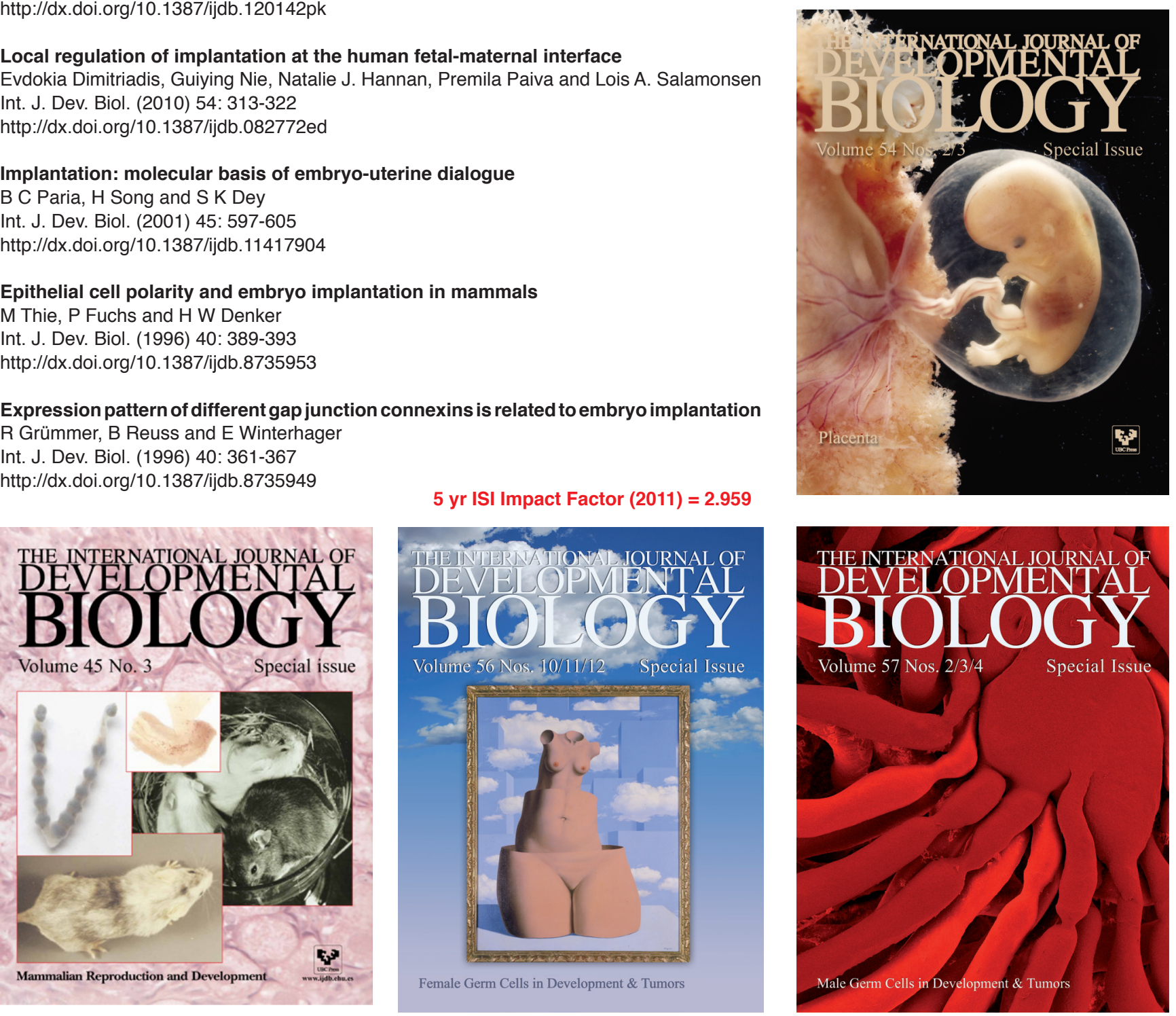